УДК 821.161.2“18/19”(092)

\title{
О.С. Лук'янова
}

\section{СЕКС І НАСИЛЬСТВО В ПОВІСТІ "КАМІННА ДУША» ГНАТА ХОТКЕВИЧА}

Цікавим явищем української літератури початку XX століття стала творчість Гната Хоткевича, зокрема його повість «Камінна душа» (1911). Визначаючи цей твір як «модерністський», дослідники (Т. Гундорова, Н. Шумило, Ю. Ковалів, А. Болабольченко, І. Приходько) все ж зосереджуються переважно на його (нео)романтично-етнографічній складовій, а саме: зображення життя і психології гуцулів. І ще принаймні два аспекти повісті, які не залишилися поза увагою, але не отримали належної експлікації, - це натуралізм у змалюванні сцен насилля та жорстокості і статева любов як об'єкт літературної рефлексії письменника.

У передмові до видання «Камінної душі» 1981 року радянський критик Олексій Засенко говорить про «некритичне <...> ставлення автора до <...> аморальних явищ у місцевому побуті» [2, с. 8], натомість Соломія Павличко відмовляє письменнику в «сміливості в еротичних сценах» [5, с. 129]. Аналізуючи його збірку «Поезія в прозі», дослідниця категорична у своєму присуді: «Хоткевич боїться теми гріха, тіла, сексу. Як правило, він обходиться натяками й поетизмами» [5, с. 126]. Однак в «Камінній душі» письменник постає вже значно сексуально розкутішим: власне, саме еротичним переживанням головної героїні відведено значну частину повісті.

Психологізм Хоткевича має біологічне підгрунтя, охоплює сфери позасвідомого та підсвідомого, виявляючи тяжіння й близькість до «філософії життя» з іiі ідеєю чуттєвості, утвердженням інстинктивного буття. Як і в деяких течіях «філософії життя» (зокрема в ніцшеанстві) тілесно-емоційні первні у героїв Хоткевича часом домінують над свідомістю, раціо.

Поетичній, романтичній натурі, Марусі «скучно» поруч із неромантичним, флегматичним і не дуже розумним отцем Василем (C) О.С. Лук'янова, 2019

http://dx.doi.org/10.34142/2312-1076.2019.1-2.91-92.10 
(невідповідність темпераментів помічає й свекруха). Проте і фізичний аспект стосунків подружжя є не менш важливим. Отець Василь виявляє чоловіче безсилля, він не здатен задовольнити жінку - після щонайменше півроку шлюбу Маруся залишається незайманою. Загалом піп постає слабкою («не твердий») людиною, боягузом, що не може захистити свою жінку від грубого домагання; він фактично уступає Марусю сильнішому супернику. Вибір героїні є визнанням нераціонального, інстинктивного, тілесного, біологічно конкурентного боку людини.

Незадоволений статевий потяг породжує тугу, причина якої спочатку незрозуміла дівчині: «А як заходив над Добушінками млосний місяць, таємний властитель приливі, притягань. Як натягував свої струни і тоскливо задзвенів мелодіями покликів і питань, - гострий неспокій заповзав у душу Марусі. Простягалися стомлені в самоті руки, заломлюючися в гнучке коло, вигинався в солодких хвилях стан, а уста розкривалися, пили холодне повітря, принесене хвилями місяця, пили й не насищалися.

І міцну в таку ніч тулилася Маруся до свого попа, жадібно й гаряче цілувала. Піп сопів, розпалювався, довго возився коло жінки, а потім, відвалившися, засипав у ту ж хвилю і хропів. А Маруся півголодна, роздражнена, довго лежала, вся в огнях, і хотіла стогнати. Засипляла під ранок неспокійним, жарким сном, до пізнього потім не вставала 3 ліжка і виходила аж під обід, стомлена, вимучена, 3 великими синцями під очима» [6, с. 95].

Сексуальний голод героїні посилюється загальною оргаїстичною атмосферою із приходом весни у Карпатські гори, також пов'язаною iз життєвідчуванням гуцулів, їхнім гедонізмом, замішаним на «поганському» досвіді. Письменник показує гуцулів як несвідомих людей («дикі»), сутність яких визначають природні інстинкти, стихійна енергія біологічного росту, що втілюється у феномені гуцульської «вільної» любові.

Весна - це свято землі, Великої Матері; коли оживає, вегетує природа, активізуються репродуктивні сили, людині теж несила опиратися могутньому потягу внутрішнього єства. Вона лише вступає в 
природну стихію й узгоджує свої кроки з біологічними ритмами: «То ще давно-давно, в сивій давнині, урочисто почали обходити цей празник (Св. Юрія. - О. Л.) оновлення тіла, празник потомства, празник будучого. [...] ...весна - празник тіла. Воно велить, воно веде, воно творить» $[6$, с. 86$]$.

Марусю захоплює ця іманентна життєва стихія; спрагла «польоту», «усолод», вона зустрічає молодого, сильного і гарного гуцула Дмитро Марусяк постає втіленням чоловічої вітальності: «Дійсно був красень. Сила тремтючим потоком переливалася в жилах, била ключем» [6, с. 138]; «Сам був життям» [6, с. 145].

Маруся поринає у світ мрій та еротичних фантазій; слухає, але по справжньому не чує Марусяка, як той вихваляється своїми любовними перемогами, брутальністю й навіть жорстокістю у поводженні 3 жінками. Зачарована поезією «вільної воленьки», вона не надавала тим словам реального значення. Уявний образ казкового лицаря заступає реального ватажка опришків - провідника кривавих злочинів.

Тілесне хвилювання від чоловічої наступальної сили характеризує маскулінну потребу дівчини. Після «прісно-несміливих ласк», «сонної любові» отця Василя наближення схильного до садизму чоловіка викликає природний відгук жіночого тіла: «Чула силу побіч себе, тверде залізне тіло, чула незнану розкіш і пила, пила їі жадібно, безумно, як земля, як природа. Стратила волю, стратила свідомість часу, розуміння добра і зла, дала себе на розбурх інстинктів...» [6, с. 192].

Марусяк виявляє себе вмілим спокусником: не поспішає, щоб не налякати Марусю, стримується, спокушає словами, грою на флоярі.

Виникнення еротичної напруги між головними героями, період «утримування», протягом якого ця напруга лише зростає, задоволення бажання - Хоткевич використовує ту схему, яка пізніше буде канонізована західним жіночим любовним романом, де головний конфлікт обов' язково містить сексуальну складову - боротьба за право володіння тілом жінки, яка опирається бажанню, але у підсумку визнає владу чоловіка над собою.

Герої розігрують ролі в «давньовічній» любовній грі, де чоловік - мисливець, ловець, а жінка - здобич, яка в упокоренні «дикій 
первобутній силі» знаходить збудження і задоволення. «Безперевна вакханалія, празник плоті, празник близькості тіл. 3 горящою головою й почуттям тільки й чекала, тільки й ждала, коли прийде, коли наступить ніч, коли опришок знов буде ласкати грубою ласкою, тиснути, давити» [6, с. 228] - із коханцем Маруся переживає той «медовий місяць», той «екстаз», якого не мала із чоловіком.

Сексуальний натуралізм повісті Хоткевича частково пояснюється, на нашу думку, вальтер-скоттівським характером нарації, де художній вимисел поєднується з історично-етнографічним колоритом (тілесна розкутість гуцулів), а також є реакцією раннього українського модернізму на сексуальну революцію, яка визнала право жінки на сексуальне задоволення нарівні з чоловіком. Соломія Павличко відзначає тогочасну загальну зацікавленість працями з психології та психіатрії (Ч. Ломброзо, М. Нордау, Р. Крафт-Ебінга тощо), книжками, «які порушували різні теми психіатрії, сексології, спадковості...» [5, с. 245]. Хоткевич змальовує не лише пристрасті всередині любовного трикутника, у творі знаходимо зображення випадків сексуальних девіацій - оргії, німфоманії i, найбільше, садистських проявів.

Проте садизм існує не лише в безпосередній формі сексуального насильства, він може сублімуватися у вигляді владолюбства, деспотизму; у будь-якому разі він визначається злочинною насолодою від наруги над людською особистістю. «Камінна душа» є надзвичайно жорстоким твором, що містить багато сцен насилля: криваві бійки, катування, згвалтування, вбивства, які автор намагається показати якомога натуралістичніше. Часто це насильство спрямоване проти беззахисних людей - жінок і дітей.

Захоплення агресивною «життєвою силою», романтизація хаосу й насилля як джерел цієї сили створюють передумови для міфологізації агресії й насильства в авангардній культурі напередодні Першої світової війни. Італійський футуризм став чи не найпершим напрямом у мистецтві, що програмно заявив про насильство як моральну та естетичну цінність (публічна лекція «Краса й необхідність насилля» Маринетті 1910 року). 
Звичайно, прямо проводити паралель між творчістю Хоткевича i футуристами недоречно, проте певні спільні тенденції мають місце. Атмосфера культурного й повсякденного життя на рубежі століть була просякнута ірраціональними хвилями агресії - страйки i демонстрації, вуличний терор, революційні заворушення, агресивна політизація суспільства тощо.

Свого часу С. Павличко писатиме про засилля риторики жорстокості, політичного і сексуального насильства в національному культурному дискурсі: «Українська література XIX-XX століть часто представляється як романтична і сентиментальна. Тим часом вона була літературою помсти. Саме в цьому впродовж століть полягав iii політичний пафос. Однак, окрім помсти гнобителям, іноземцям та іновірцям, не менше місця в ній займало на перший погляд безпричинне насильство, передовсім по відношенню до жінок. А також істерична ненависть носіїв цього насильства до себе» [5, с. 591]. Носіями такої «злоякісної дестуктивності» (Е. Фромм) постають героїантагоністи Марусяк і Юрішко-Юріштан, отаман пушкарів.

Початок конфлікту - виникнення агресивної конкуренції між чоловіками за об'єкт (жінку), який бажає інший. Несправедливість, вчинена щодо Марусяка, й жадоба помсти кривдникам, накладаючись на «буйний» темперамент хлопця, стають каталізатором руйнівного інстинкту. «Романтичний герой усе ж вважає, що він змушений творити зло через ностальгію добра, якого неможливо сягнути» [3, с. 218], - не без іронії зауважує Альбер Камю. Проте говорити про боротьбу за відновлення справедливості немає підстав, оскільки ватажок опришків навіть не намагається виступати у ролі народного месника - захисника покривджених.

Відомий німецький соціолог, філософі психоаналітик Еріх Фромм у своїй фундаментальній праці «Анатомія людської деструктивності» робить припущення щодо причин для помсти: «Очевидно, людина тоді береться вершити правосуддя, коли вона втрачає віру... У своїй жадобі помсти вона більше не потребує авторитетів, вона “вищий суддя", i, вчиняючи акт помсти, вона відчуває себе і ангелом, i Богом... це ії зірковий час» [7, с. 273]. Марусяк отримує насолоду від 
своєї необмеженої влади над іншими: «Весь у червонім, тримаючи в руках життя і смерть усіх присутніх, він стояв, мовби який боггромовержець (курсив. - О. Л.), що злетів з недоступних гір, - і чув це, чув свою міць, свою власть над душами цих людей» [6, с. 138].

Героєм часто рухає марнославство (показовий епізод, пов'язаний iз подіями у Ясеневі). Загалом Марусяк має риси нарцисичної особистості - дає волю самозамилуванню і агресивно реагує на загрозу втрати визнання, а далі й авторитету і, відповідно, влади і впливу.

Жорстокість Марусяка певною мірою пояснюється брутальністю життя опришків, адже залежність особистості від соціального середовища, в якому вона знаходиться, є високою. Опришки визнають лише одне право - право сили. (Але навіть у такому середовищі існує опір надмірній жорстокості - опришки виявляють співчуття до Марусі; Бідочуків потай повертається, щоб розв'язати ії, у такий спосіб рятуючи від смерті).

Зневага до жінки, ставлення до неї, як до речі, якою можна розпоряджатися на власний розсуд, наприклад, відступити товаришеві, тут є нормою. Марусяк дає волю своїм садистським імпульсам: відчуваючи збудження від насилля, він гвалтує, знущається, ображає і публічно принижує Марусю. «Змусити когось відчути біль або приниження, коли цей хтось не має можливості захистити себе, - це вияв абсолютного панування» [7, с. 289] - владою над безпомічною і беззахисною істотою він компенсує свої поразки і невдачі. Психічний садизм виявляється в тому, що «Марусяк користав 3 кожної хвилі, коли можна було чимось уколоти попадю. Бити не бив і не знущався вже дико, але словами гриз гірше, як зубами» [6, с. 337]; «...коли говорив до неї, то самими лайками. Вже інакше не називав, як: «Гей ти, курво моя!» - і плів усяку брудоту, котра лиш приходила в голову. Навіть опришки - спочатку сміялися, а потім перестали: занадто вже...» [6, с. 310]. Найвищий вияв нелюдської жорстокості згвалтування Катерини на очах у Марусі.

Автор все-таки робить спробу виправдати свого героя: Марусяк приймає власну долю і усвідомлює наслідки власного вибору (метафора каменя, що падає вниз). Як писав А. Камю в «Бунтівній 
людині»: «Своєрідний стоїцизм пороку кидає слабкий промінь на це дно бунту. [...] ... стоїцизм змириться із власною загибеллю. Розкута сила відмови вдається до крайніх заходів, беззастережно приймає їх, і все це не позбавлено величі» [3, с. 215]. Засуджений до страти, Марусяк гідно йде на смерть.

Якщо образ Дмитра Марусяка є амбівалентним, то на іншому полюсі зображено іноземця, представника імперської влади в регіоні, мандатора Устерік Гердлічку, садизм якого має виразні ознаки клінічної патології, а сам він - біологічного виродження. Як визначає Е. Фромм, садизм - це «релігія духовних калік» [7, с. 290]; «...єдиний спосіб заглушити це нестерпне почуття нікчемності і якоїсь “вітальної імпотенціі” - самоствердитися за будь-яку ціну, хоча б варварським руйнуванням життя» [7, с. 366].

Людина, наділена владними повноваженнями, не стає автоматично садистом, але можливість реалізації необмеженої влади дає відчуття безкарності, тоді як «безкарність - суттєва умова для садистичного експерименту» [1]. У системі тогочасних соціальних відносин отаман пушкарів має владу, меж якої не знає навіть сам, і ця влада спирається виключно на силу, страх і покору: «Часом у нього аж у голові мутилося, і він сам не знав, що робити зі своєю властю, щоб відчути ії до кінця, щоб насолодитися до решти» [6, с. 180] (бартка і гарапник - атрибути цієї влади).

Усе це ускладнюється особистими проблемами Юріштана. Він сподівається покорити Катерину, змусити їі полюбити себе, але в нього нічого не виходить, і тоді він намагається компенсувати цю неспроможність прагненням до влади над іншими людьми. Юріштан нещаслива, самотня людина. Віктор Срофеєв пише: «...прорив із самотності, що стала глобальною, здійснюється садистичним героєм в акті насильства, який, маючи в собі суттєвий момент самоствердження і будуючись на стосунках “кат - жертва", якраз і дає йому найвищу насолоду. Мова насильства - єдина мова, якою здатен розмовляти садистичний герой. [...] Акт насилля... стає для садистичного героя нагальною потребою, адекватною потребі нормальної людини в комунікації [1]. 
Маючи владу, він може вбивати і мучити, але все одно залишається нещасною, ніким не любимою і нікому не потрібною людиною: «Мстив усім за дисгармонію свого життя, божеволів і, мов запійний п’яниця, не міг уже обійтися без своєї отрути. ... Бачив безодню під ногами, чув, як ніхто, все безумство, всю потворність своїх учинків - і ліз, і ліз все глибше у кров'яне море, щоби на ранок шукати кров'яного ж похмілля» [6, с. 263]. Озлоблений на весь світ, він культивує в собі цю ненависть, обрушуючи ії на невинну, беззахисну дитину. Апофеозом стає моторошна, шокуюча своєю жорстокістю сцена побиття Катерини. Жінка, над якою щойно поглумився чоловік, якого вона кохала, зазнає нових страшних мук, проте і цього мало Юрішкові - він демонструє диявольську вигадливість у знущанні над Катериною, роблячи його показовим.

Незважаючи на всю огидність вчинків Юріштана, автор у чомусь симпатизує цій «могутній людині», «сильній душі» (вплив ніцшеанського культу сили?), пояснюючи його жорстокість «темнотою» простого гуцула: Юріштан «одурений своєю властю, нещасливий в родиннім життю і вибитий тим 3 нормальних відносин» [6, с. 182] (Хоткевич кілька разів використовує саме це слово «одурений»).

У своєму садистському експерименті Юрішка можна порівняти із Калігулою з п'єси Камю - він випробовує межі терпіння, прагне, щоб проти нього збунтувалися: «І йому хотілося, аби вони бодай лаялися, відгрожувалися, збиралися мститись, але се були звичайні смирні люди, терпеливі, як вівці [6, с. 263]; «...все чекав - коли ж це плюне йому хто-небудь в лице, коли ж назове його хтось так, як належиться. Але ніхто не плюнув, ніхто не назвав» [6, с. 331] - ксьондз як завжди благословив Юріштана першим.

Сумний результат цього злочинного експерименту: в існуючій соціальній (ієрархічній) системі покора й послух закорінені чи не в самому характері людини. Щодо Калігули, то він робить цинічний висновок: «Чесність, респектабельність i, як там ще кажуть, мудрість нації - це вже пусті слова. Усе зникає перед страхом. Адже так, Кезоніє, страх - це гарне почуття, чисте й безстороннє, без домішок, одне 3 небагатьох, шляхетних уже від самого початку» [4]. 
Протагоніст п'єси Камю доводить свій бунт до логічного завершення - забираючи чиєсь життя, він згоден померти сам, тоді як для героя Хоткевича все закінчується нападом мазохістичного самопониження (а потім почуттям сорому і жадобою помсти за приниження), що, по суті, «не протилежність садизму, а частина симбіотичної структури особистості, в якій повний контроль і повна покірність лише вияв тієї самої глибокої життєвої імпотенції» [7, с. 315].

Ще один аспект, на кому хотілося б зупинитися. Е. Фромм доводить, що деструктивність виникає як можлива реакція на психічні потреби, вкорінені у людському житті, і що вона є результатом взаємодії різноманітних соціальних умов і екзистенційних потреб людини. Однією з таких потреб є потреба в прихильності - відчутті зв'язку з іншими людьми і світом. У світлі цього цікаве зауваження Хоткевича щодо особливостей психології гуцула, а саме його індивідуалізму — все життя сам по собі, «сили єднання він не розуміє» [6, с. 134]; фіксує письменник і агресивність («ненависть») у стосунках між статями. Твір Хоткевича засвідчує: патріархальне суспільство легітимізує насильство над жінкою («У своїм стані знав, єк то мало би йти: виволочив би газда добре на всі боки та й спокій голові...» [6, с. 339]; «Най би вже попобив (чоловік. - О. Л.) си трохи, бо без того не буває у хаті...» [6, с. 240]). Домашнє насильство також виявляється як психологічний (заборона Дмитрові одружуватися з нерівнею) i фізичний (систематичне биття Катерини махучою) тиск батьків на дітей. Отже, людські стосунки постають деформованими патріархальними нормами. Проблема домашнього насильства виходить за межі суто літературної і, на жаль, не втрачає своєї актуальності.

Отже, віталізм і психоаналітика Гната Хоткевича у «Камінній душі» суголосні пошукам доби порубіжжя: інтерес до сексуальної проблематики і визнання позараціональності пристрастей, які часто керують людським життям; аналіз деструктивних потягів, зокрема садизму як жадоби абсолютної влади над іншою істотою, що супроводжувалося наближенням Першої світової війни, i, зробимо припущення, все-таки критика патріархального устрою, який узвичаює насильство. Надмірна жорстокість героїв викликана не лише 
соціальними, а й особистими, психологічними причинами, проте домінування в соціумі культу сили, створює замкнене коло насильства, вирватися з якого дуже важко.

\section{Література}

1. Ерофеев В. Маркиз де Сад, садизм и XX век. URL: http://royallib.com/ $\mathrm{read} /$ erofeev_viktor/markiz_de_sad_sadizm_i_XX_vek.html\#0 (дата звернення: 19.04.2019).

2. Засенко О. Гнат Хоткевич і його повість «Камінна душа». Хоткевич Г. Камінна душа. Київ: Дніпро, 1981. С. 3-14.

3. Камю А. Вибрані твори: у 3 т. Т. 3. Есе. Харків: Фоліо, 1997. 623 с.

4. Камю А. Калігула. URL: https://www.ukrlib.com.ua/world/printit.php? tid=3228 (дата звернення: 19.04.2019).

5. Павличко С. Теорія літератури. Вид. 2-е. Київ: Основи, 2009. 679 с.

6. Хоткевич Г. Авірон. Камінна душа. Харків: Фоліо, 2009. 380 с.

7. Fromm E. The Anatomy of Human Destructiveness. URL: http://lustfor-life.org/Lust-For-Life/_Textual/ErichFromm_TheAnatomyOfHuman Destructiveness_1973_534pp/ErichFromm_TheAnatomyOfHumanDestruc tiveness_1973_534pp.pdf (дата звернення: 19.04.2019).

\section{References}

1. Yerofeiev, Viktor. Markiz de Sad, sadism i XX vek [Marquis de Sade, sadism and the 20th century]. URL: http://royallib.com/read/erofeev_viktor/ markiz_de_sad_sadizm_i XX_vek.html\#0.

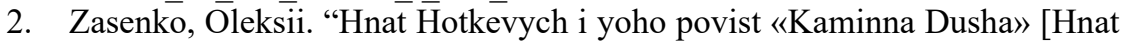
Hotkevych and his novel «The Stone soul»]." In Kaminna Dusha by Hnat Hotkevych, 3-14. Kyiv: Dnipro, 1981.

3. Hotkevych, Hnat. Aviron. Kaminna Dusha [Abiram. Stone soul]. Kharkiv: Folio, 2009.

4. Kamiu, Alber. Kalihula [Caligula]. URL: https://www.ukrlib. com.ua/world/ printit.php?tid=3228.

5. Kamiu, Alber. Vybrani tvory [Selected works]: u 3 t. T. 3. Kharkiv: Folio, 1997.

6. Pavlychko, Solomiia. Teoriia literatury [Theory of literature]. Kyiv: Osnovy, 2009.

7. Fromm E. The Anatomy of Human Destructiveness. New York, Chicago, San Francisco: Holt, Rinehart \& Winston, 1973. http://lust-for-life.org/LustFor-Life/_Textual/ErichFromm_TheAnatomyOfHumanDestructiveness_19 73_534pp̄/ErichFromm_TheAnatomyOfHumanDestructiveness_1973_ $\overline{5} 34$ pp.pdf. 


\section{Анотація \\ О.С. Лук'янова. Секс і насильство в повісті «Камінна душа» Гната Хоткевича}

Стаття присвячена аналізу повісті Гната Хоткевича «Камінна душа», написаної на початку XX століття. Незважаючи на виражений етнографічний елемент, твір доцільно розглядати в контексті актуальної модерністської проблематики, зокрема проблеми сексуальності, у тому числі й жіночої, 3 одного боку, й посиленої маскулінізації світу, що супроводжувалася риторикою насильства та жорстокості, - 3 іншого. Психоаналітика «Камінної душі» актуалізує нераціональний, тілесний і біологічно конкурентний бік людини, виявляючи близькість до «філософії життя» з її ідеєю чуттєвого, інстинктивного буття. Сексуальний натуралізм повісті Хоткевича виявляється не лише в змалюванні пристрастей усередині любовного трикутника, у творі знаходимо зображення випадків сексуальних девіацій - оргії, німфоманії, садизму.

Загалом, атмосфера культурного й повсякденного життя на межі століть була просякнута ірраціональними хвилями агресії - страйки, демонстрації, вуличний терор, революційні заворушення, агресивна політизація суспільства тощо. Захоплення агресивною «життєвою силою», романтизація хаосу й насилля як джерел цієї сили створюють передумови для міфологізації агресії й насильства (насамперед в авангардній культурі) напередодні Першої світової війни.

«Камінна душа» є надзвичайно жорстоким твором, що містить багато сцен насилля; часто насильство спрямоване проти беззахисних людей жінок і дітей. Головні чоловічі персонажі повісті демонструють сильний садистський потяг як сексуального, так і несексуального характеру, адже садизм може сублімуватися в деспотизм, жадобу абсолютної влади над іншою істотою.

У розвідці ми намагалися з'ясувати психологічні й соціальні причини такої деструктивної поведінки поза романтичною ідеалізацією. Окремим напрямом подальших досліджень може стати проблема домашнього насильства, легалізованого патріархальними нормами.

Ключові слова: модернізм, інстинкт, статева любов, насильство, влада, сила.

\section{Аннотация}

О.С. Лукьянова. Секс и насилие в повести «Каменная душа» Гната Хоткевича

Данная статья посвящена анализу повести Гната Хоткевича «Каменная душа», которая была написана в начале XX века. Несмотря на выраженный 
этнографический элемент, произведение целесообразно рассматривать в контексте актуальной модернистской проблематики, в частности проблемы сексуальности, в том числе и женской, с одной стороны, и возросшей маскулинизации мира, что сопровождалась риторикой насилия и жестокости, - с другой. Психоаналитика «Каменной души» актуализирует нерациональную, телесную и биологически конкурентную сторону человека, демонстрируя близость к «философии жизни» с ее идеей чувственного, инстинктивного бытия. Сексуальный натурализм повести Хоткевича проявляется не только в изображении страстей внутри любовного треугольника, в произведении можно найти описание случаев сексуальных девиаций - оргии, нимфомании, садизма.

В целом, атмосфера культурной и повседневной жизни на рубеже веков была пронизана иррациональными волнами агрессии - забастовки, демонстрации, уличный террор, революционные волнения, агрессивная политизация общества. Увлечение агрессивной «жизненной силой», романтизация хаоса и насилия как источников этой силы создают предпосылки для мифологизации агрессии и насилия прежде всего в авангардной культуре накануне Первой мировой войны.

«Каменная душа» является чрезвычайно жестоким произведением, в котором много сцен насилия; часто насилие направлено против беззащитных людей - женщин и детей. Главные мужские персонажи повести демонстрируют сильные садистические наклонности как сексуального, так и несексуального характера, ведь садизм может сублимироваться в деспотизм, жажду абсолютной власти над другим существом.

В статье мы пытались выяснить психологические и социальные причины такого деструктивного поведения без романтической идеализации. Отдельным направлением дальнейших исследований может стать проблема домашнего насилия, легализированного патриархальными нормами.

Ключевые слова: модернизм, инстинкт, половая любовь, насилие, власть, сила.

\section{Summary \\ O.S. Lukianova. Sex and Violence in The Stone Soul Novel by Hnat Khotkevych}

This article is devoted to the analysis of Hnat Khotkevych The Stone Soul (Kaminna Dusha), written in the early twentieth century. Despite the pronounced ethnographic element, this work should be considered in the context of the modernist issues of the time, in particular problems of sexuality, including female, on the one side, and intensified masculinisation of the world accompanied by the rhetoric of violence and cruelty, on the other side. The psychoanalytics of The 
Stone Soul actualizes the irrational, instinctual, corporal and biologically competitive side of a person, thus revealing a proximity to the philosophy of life with its idea of sensual, instinctive 'being'. Sexual naturalism of Khotkevych's story is shown not only in the depiction of the passions inside the love triangle, but this work also describes cases of sexual deviations - orgy, nymphomania and sadism.

In general, the atmosphere of cultural and everyday life at the turn of the century was imbued with irrational waves of aggression - strikes, demonstrations, street terror, revolutionary riots, aggressive politicization of society. The admiration for aggressive 'life force', the romantisization of chaos and violence as sources of this force create the preconditions for the mythologization of aggression and violence firstly in the avant-garde culture just before World War I.

The Stone Soul is an extremely cruel work that contains many scenes of violence; this violence is often directed against defenseless people - women and children. The main male characters of the novel demonstrate a strong sadistic inclination, both sexual and non-sexual, however sadism can sublimate to the despotism, the passion for absolute and unrestricted power over another human being.

In this research we tried to find out the psychological and social causes of such destructive behavior beyond romantic idealization. The problem of domestic violence legalized by patriarchal norms may be a separate direction for further research.

Keywords: Modernism; Instinct; Sexual Love; Violence; Power; Force.

\section{Інформація про автора}

Лук'янова Ольга Сергіївна - кандидат філологічних наук, в.о. доцента кафедри української і світової літератури імені професора Леоніда Ушкалова Харківського національного педагогічного університету імені Г.С. Сковороди; вул. Валентинівська, 2, м. Харків, 61168, Україна; https:/orcid. org/0000-0002-6095-0425. 